\title{
Antimicrobial Efficiency of Edible Films in Food Industry
}

\author{
Dan Cristian VODNAR ${ }^{1}$, Oana Lelia POP ${ }^{1}$, Francisc Vasile DULF ${ }^{2}$, Carmen SOCACIU ${ }^{1 *}$ \\ ${ }^{I}$ University of Agricultural Sciences and Veterinary Medicine, Department of Food Science, 3-5ManasturSt, 400372 Chij-Napoca \\ Romania;dan.vodnar@usamvchij.ro;oana.pop@usamvchij.r;;carmen.socaciu@usamvchi.ro(*orrespondingauthor) \\ ${ }^{2}$ University of Agricultural Sciences and VeterinaryMedicine, Department Environmental and Plant Protection, 3-5 Manastur St., 400372 Chij-Napoca, \\ Romaniajfranciscdulf@usamvchi.ro
}

\begin{abstract}
In the current article, several applications of materials in food packaging and food safety are reviewed, including: polymers as high barrier packaging materials, natural substances as potent antimicrobial agents, and the efficiency of antimicrobial films in food industry. The first condition of all this materials in order to be utilised in food industry is to fall into the list of generally accepted as food grade. Active antimicrobial food packaging systems are supposed not only to passively protect food products against environmental factors, but also to inhibit or retard microbial growth on the food surface, extending the shelf life of products. Edible films can be incorporated into conventional food packaging systems with a dual purpose as an edible and antimicrobial component. Several benefits resulting from the application of the antimicrobial films, embedded with various natural antimicrobials, on different food products as fruits, vegetables and meat products lead to various benefits as maintaining the products freshness for longer time, extend product shelf life and reduce the risk of pathogen growth. Thus, food graded antimicrobial packaging films are promising food packaging materials because its biodegradability provides sustainable development for modern community by reducing the use of drugs as chemical antibiotics, reducing economic losses and overall increases the trust of the final consumer in food products.
\end{abstract}

Keywords: antimicrobials, edible films, fruits and vegetables, meat products, natural compounds

\section{Introduction}

The current global market has experienced an increasing of the consumers demand for better quality of life. Meeting the criteria of high quality and reduce the use of chemicals in order to obtain food safety products are few of the factors contributing to this demand. This has lead companies and researchers to explore different ways to improve their productivity in terms of maintaining quality, freshness and food safety, such as using sustainable materials in food packaging (Mahalik and Nambiar, 2010). The emergence of bacterial antibiotic resistance and negative consumer attitudes regarding chemical food preservatives has induced an increased interest in the use of natural antimicrobial molecules as alternative agents for the control of food spoilage and hazardous pathogens. Foodborne diseases produce a wide range of diseases and are activated by agents that were ingested along with food. As declared by the authorities [World Health Organization (WHO), Centres for Disease Control and Prevention (CDC)], the spoilage of food may occur at any stage in the process from food production to consumption ("farm to fork") and in many of this cases the pathogens are to blame (Srey et al., 2013).

There has been an increasing interest during recent years to develop materials with film-forming capacity and having antimicrobial properties that help to improve health safety and shelf life (Fakhouri et al., 2015; Genskowsky et al., 2015).
Antimicrobial packaging is one of the most effective in killing or inhibiting pathogenic microorganism growth that contaminate foods (Salleh et al., 2007). Contamination could occur when food is being exposed under distinct conditions during slaughtering, post processing, distribution and shipping. (Sung et al., 2013). Thus, a good packaging is required in order to reduce the contamination into the food.

There is a current trend in food packaging systems concerning about developing new innovative concepts to inhibit pathogenic microbial activities in food (Ge et al., 2015; Ollé Resa et al., 2014). Up to now, products as active and intelligent packaging systems have been developed in order to meet significant safety requirements (Han, 2014). Antimicrobial packaging located within the group of active packaging are made from wrapping system containing antimicrobials (natural or synthetic agents) (Sung et al., 2013). Utilization of antimicrobial packaging is more advantages compare to direct adding of antimicrobial agents onto food products due to the fact that the cover, containing the active agent, can be remove just before product consumption so the antimicrobial will not be ingested together with the product (Salgado et al., 2015). Surface application of antimicrobials represents an alternative to direct application and is based on the incorporation of an antimicrobial compound into an edible coating that is then applied on the food surface (Vodnar, 2012). The choice of active agents that may be 
incorporated into edible films could influence the consumers perception regarding the ingredients listed on product label (Vodnar, 2012).

Edible films are thin films prepared from materials, which act as a barrier to external factors and thus protect the food product, extend its shelf life and improve its quality (Suyatma et al., 2005). An edible film is defined as a performed thin layer or solid sheets of material placed on or between food components (Galus and Kadzińska, 2015). The edible films could be applied on food products as film wraps or pouches for food. The use of edible films in food protection and preservation has increased in the last decade since they can offer several advantages (high antimicrobial effect with minimum sight effects, increasing the trust of the consumer, reducing the economic costs etc.) over synthetic materials, such as being biodegradable and environmentally friendly (Tharanathan, 2003).

The most commonly occurring and applied natural polymers include: polysaccharides (starch, cellulose and its derivatives, alginate, chitosan, gellan gum), proteins (collagen, zein, soybean, gluten proteins, milk proteins) and fats (beeswax, candelilla wax, fatty acids and glycerols) (Casariego et al., 2008). One important advantage of this type of packages is the fact that they might be consumed together with the food product (Suyatma et al., 2005).

The functionality of edible film materials may vary, as each component confers different properties on the composite matrix. Polysaccharides or proteins used in film formulation usually have suitable mechanical and gas barrier properties and poor water vapour barrier properties. On the other hand, films from lipids exhibit good water vapour barrier properties, poor mechanical strength, and high oxygen permeability.

\section{Antimicrobial food packaging materials}

Antimicrobial packaging can be generally divided into two major groups: biodegradable packaging and non-biodegradable packaging. The synthetic polymers have the advantages of low cost materials, low density, inert, excellent barrier properties, good mechanical strength, high transparency, ability to be heat sealed and easy to be printed, but are not biodegradable (Akter $e t$ al., 2012; Bonilla et al., 2012; Pattanayaiying et al., 2015). The most common plastics used in food packaging are: low, linear and high density polyethylene, polypropylene, polystyrene, ethylene vinyl acetate, polyethylene terephtalate and polyvinyl chloride (Sung et al., 2013). The main disadvantages of these materials are: the diffusion of additives from polymers into food products and the negative impact to the environment (Akter $e t$ al., 2012).

Currently, biodegradable antimicrobial films are produce from natural polymers incorporating natural or synthetic antimicrobial agents (Han, 2014). Most of the literature reports are focused on the blending of thermoplastic starches with biodegradable polyesters such as: polycaprolactone, polylactic acid, polyhydroxibutyrate-co-hydroxyvalerate, polybutylene succinate-adipate, poly (butylenes adipate-co-therephtalate) and poly (hydroxyl ester ether) (Agarwal, 2012; Mahieu et al., 2015; Terzopoulou et al., 2015).

Polylactic acid (PLA)

Is one of the most promising biopolymer (due to relative low melting temperature, its ability to form compact films, increase the biocompatibility of many active accents etc.) with industrial applications able to replace the petroleum-derived polymers. PLA is linear aliphatic thermoplastic polyester derived from $100 \%$ renewable resources, which is produced by the fermentation of biomass (Armentano et al., 2013; Vodnar et al., 2010). It is a thermoplastic polymer with high-strength, highmodulus, good processability, being completely biodegradable, compostable, and biocompatible (Djidi et al., 2015; Ingrao et al., 2015; Jašo et al., 2015). In addition, PLA is safe for the food packaging application since it has been proven GRAS for use in food packaging to fulfill the requirements for direct contact with aqueous, acidic and fatty foods (Rhim, 2013). PLA's potential for consumer products such as packaging is remarkable due to its transparency, low toxicity and environmentally benign characteristics (Dutta et al., 2009). There are limited studies investigating the antimicrobial efficiency of antimicrobials as lemon extract, thymol, lysozyme (Del Nobile et al., 2009), olive leaf extract (Marcos et al., 2014) incorporated into PLA films.

\section{Chitosan}

A linear polysaccharide consisting of $(1,4)$-linked 2-aminodeoxy- $\beta$-D-glucan, is a deacetylated derivate of chitin which is the second most abundant polysaccharide found in nature after cellulose (Dutta et al., 2009). The deacetilation is usually incomplete, thus chitosan is a copolymer comprised of deacetylated and acetylated units. Chitosan has been found to be non-toxic, biodegradable, biofunctional, biocompatible in addition to heaving antimicrobial characteristics (Jayakumar $e t$ al., 2007). Chitosan is especially of interest for the antimicrobial packaging and biomaterials industry because is cationic and naturally antimicrobial properties. Comparing with other biobased food packaging materials, chitosan has the advantage of being able to incorporate active and functional substances with antimicrobial activities against Listeria monocytogenes for example (Moller et al., 2004; Vodnar, 2012).

Chitosan because of the positive charge has a better antimicrobial activity than chitin. The exact mechanism of chitosan and its derivatives is still perfectly unknown, but the literature reported different potential explanations (Rabea $e t$ al., 2003). One of the reasons of the antimicrobial character of chitosan is its positively charged amino group, which interacts with negatively charged microbial cell membranes (Shahidi et al., 1999). On the other hand, chitosan acts as chelating agent that selectively binds trace metals and thus inhibits the production of toxins and microbial growth (Cuero et al., 1991). The antimicrobial mechanism of chitosan were different from Gram-positive ( $S$. aureus) and Gram negative (E. coli) bacteria (Zheng and Zhu, 2003). The authors have reported the effects of chitosan on Staphylococcus aureus (Gram-positive) and Escherichia coli (Gramnegative) bacteria. The antimicrobial activity increased once with the molecular weight of chitosan against $S$. aureus, while for $E$. coli, the antimicrobial activity increased once with decreasing molecular weight of chitosan. The authors proposed one explanation for each antimicrobial activity: (I) in case of $S$. aureus, chitosan form a polymer membrane, which inhibits nutrients from entering the cell and (II) for E. coli, chitosan entered the cell through pervasion.

Chitosan nanoparticles are prepared by interaction of oppositely charge macromolecules (de Azeredo, 2013). Chitin 
304

whiskers (crystalline nanofibrils) can be prepared by acid hydrolysis of chitin and a subsequent diacetylation of chitin whiskers produces chitosan whiskers. Chitosan nanoparticles and their derivatives have wide antimicrobial effects (Madureira et al., 2015). Chitosan nanoparticles (in concentrations from 0,1 to $0,7 \% \mathrm{w} / \mathrm{v}$ ) present higher antimicrobial effect than bulk chitosan because of their higher surface area and charge density, providing a higher interaction with the cationic surface of bacterial cells (Madureira etal.,2015).

The antimicrobial effect of nanostructures combining chitosan and other antimicrobial agents has been studied by many researchers (Ramani et al., 2014; Song and Jang, 2014). Carvacrol-loaded chitosan nanoparticles were obtained by oil-inwater emulsion followed by ionic gelation of chitosan (Keawchaoon and Yoksan, 2011). The minimum inhibitory concentration indicated that carvacrol increased the antimicrobial activity of chitosan nanoparticles against $E$. coli, S. aureus, Bacillus cereus.

\section{Pectin}

Is one of the main components of the plant cell wall, contributing to tissue rigidity and integrity and is considered one of the most complex macromolecules in nature (Bayarri et al., 2014; Benito-Peña et al., 2016; De'Nobili et al., 2015; Tripathi et al., 2010). The most important sources for pectin extraction are apple pomace and citrus peels (Videcoq et al., 2011). Pectin is an ingredient used in food industry with no limitation other than current good manufacturing practice, is considered as generally recognized as safe by FDA, and it was used in food mainly as gelling, stabilizing or thickening agent in products such as yogurts, jams, drinks and ice cream (Laurent and Boulenguer, 2003).

\section{Soyprotein isolate}

Is a complex mixture of proteins with widely different molecular properties; ranging from 200 to $600 \mathrm{kDa}$. The major soybean protein group is globulins, which can be fractionated in $2 \mathrm{~S}, 7 \mathrm{~S}, 11 \mathrm{~S}$ and $15 \mathrm{~S}$ according to their sedimentation coefficient. The $7 \mathrm{~S}$ and $11 \mathrm{~S}$ fractions are the main fractions and represent between $31 \%$ and $37 \%$ of the total extractable protein. This fractions have the capability of polymerization (Cho and Rhee, 2004). Soy protein isolate is a protein with reproducible resource, good biocompatibility, biodegradability, processability and film forming capacity that has significant potential for use in the food industry, agriculture, bioscience and biotechnology (Khan et al., 2012).

\section{Alginates}

Are structural polysaccharides extracted from brown algae. In molecular terms, alginates are linear water-soluble polysaccharides comprising (1-4) linked units of R-Dmannuronate and $\hat{a}$-L-guluronate at different proportions and different distributions in the chain (Hambleton et al., 2011). Most applications of alginate is based on its gel-forming ability through cations binding; the transition from water-soluble sodium alginate to water insoluble calcium alginate (Galus and Kadzińska, 2015). Sodium alginate-based edible films can be used to limit dehydration of meat, fish and fruits. Alginate can also be support of active substances, like encapsulation agent (Popetal., 2015).

\section{Wheyproteins}

Have exceptional nutritional value and functional (Banerjee and Chen, 1995). More, liquid whey is produced in large quantities and its annual production increases continuously (Banerjee and Chen, 1995). The establishment of edible films and coatings from whey proteins can increase the utilization of whey, improve nutritional value of foods and prolong the shelf life (Ozdemir and Floros, 2008). Whey protein isolates represent the purer form of whey proteins and have shown promising mechanical features. Other valuable properties of the whey protein isolates are moderate moisture permeability ( $\mathrm{McHugh}$ et al., 1994) and good oxygen barrier properties-comparable to those exhibited by the best synthetic polymer based films available.

\section{Natural compounds in antimicrobial edible films}

The antimicrobial substances most frequently introduced into films are: bactericins, enzymes, oils, plant extracts and preservatives (Angiolillo et al., 2014; Calo et al., 2015; Ríos and Recio, 2005; Wang et al., 2015). The antimicrobial activities of essential oils and plant extracts are well known for a long time and numerous research papers (Acevedo-Fani et al., 2015; Akhavan et al., 2015; Ankri and Mirelman, 1999; Aumeeruddy-Elalfi et al., 2015; Basgedik et al., 2015; Cottigli et al., 2001; Pesavento et al., 2015) have been published on the antimicrobial activities of plant essential oils against foodborne pathogens. Essential oils are complex mixtures of volatile organic compounds produced as secondary metabolites in plants; they are constituted by hydrocarbons (terpenes and sesquiterpenes) and oxygenated compounds (alcohols, esters, aldehydes, ketones, lactones, phenols and phenol esters) and possess highly inhibitory potential to a wide spectrum of microorganisms. A number of authors have mentioned the antimicrobial activity of essential oils; however, the mechanism of action has not been studied in detail (Kon and Rai, 2013). It is generally believed that essential oils principally performed against the cell cytoplasmic membrane of microorganism (Zabka et al., 2014). The essential oils hydrophobicity enables them to be accumulated in cell membranes, disturbing the structures and causing an increase of permeability. Leakage of intracellular components and impairment of microbial enzymes systems can than occur (Carson et al., 2002) and extensive loss of the cell contents will cause the cell death (Lv et al., 2011). Examples of plant extracts and essential oils most widely incorporated into food packaging systems are: linalool, thymol, carvacrol, clove oil, cinnamaldehyde basil essential oils and teas (Mihaly Cozmuta et al., 2015).

Due to the consumers demand with less use of chemicals on minimally processed food products, more attention has been paid in searching for naturally occurring substances able to act as alternative antimicrobials and antioxidants (Atarés et al., 2010).

Some studies have shown that essential oils of oregano (Origanum vulgare), thyme (Thymus vulgaris), cinnamon (Cinnamon cassia), lemongrass (Cymbopogon citrates) and clove (Eugenia caryphyllata) are among the most active against strain $E$. coli (Emiroğlu et al., 2010; Martucci et al., 2015; Pranoto et al., 2005b; Zivanovic et al., 2005). The effectiveness of these compounds has been reported previously, more carvacrol (the major component of oregano and thyme) appears to receive the most attention from researchers. 
Friedman et al. (2002), investigated 120 naturally plant derived oils and oil compounds for their antimicrobial activities against four species of foodborne pathogens. The most active oils in terms of $\mathrm{BA}_{50}$ values (\% of oil in phosphate buffer that killed $50 \%$ of bacteria) for Campylobacter jejuni $\left(\mathrm{BA}_{50}, 0.003-0.009 \%\right)$ are: marigold, ginger root, jasmine, patchouli, gardenia, cedarwood, carrot seed, celery seed, mugwort, spikenard and orange bitter; and for E. coli $\mathrm{O} 157 \mathrm{:H} 7\left(\mathrm{BA}_{50}, 0.046-0.14 \%\right)$ : oregano, thyme, cinnamon, palmarosa, bay leaf, clove bud, lemon grass and allspice, for Listeria monocytogenes $\left(\mathrm{BA}_{50}, 0.057-0.092 \%\right)$ : gardenia, cedarwood, bay leaf, clove bud, oregano, cinnamon, allspice, thyme and patchouli, for Salmonella enteric (BA $\left.\mathrm{BA}_{50}, 0.045-0.14 \%\right)$ : thyme, oregano, cinnamon, clove bud, allspice, bay leaf, palmarosa and marjoram.

More, Friedman et al. (2004) showed that carvacrol, oregano and cinnamaldehyde were effective antibacterial against antibiotic resistant B. cereus, $C$. jejuni, E .coli, S. enteric and $S$. aureus. Films with preservatives additions such as benzoates, sorbates should be characterized by a wide range of activities against pathogenic microorganisms which can cause food spoilage (Quintavalla and Vicini, 2002).

The most popular products of microbial metabolism are: nisin-a bacteriocin of Lactoobacillus lactis bacteria and pediocin -a bacteriocin of Pedicococcus acidilactici bacteria (Tong et al., 2014) (Table 1).Literature reports have been describing attempts of their application in many matrices. Nisin is usually applied in film based on proteins of whey, zein, wheat and soybean (Ko et al., 2001). A significant antimicrobial effect against Salmonella enteritidis and Listeria monocytogenes was achieved in case of film based on zein with nisin addition (Hoffman et al, 2001).

Coma et al. (200I) described the antimicrobial activity of nisin incorporated into cellulose or hydroxypropylmethylcellulose film against $L$. innocua and $S$. aureus. Other investigations were conducted with nisin being into a film from methylcellulose and hydroxypropylmethylcellulose witch are good matrices for bactericidal substances immobilization and are characterized by elasticity and resistance. The obtained films showed an inhibitory activity of Micrococcus luteus growth. Another investigated bacteriocin was pediocin which was introduced into the cellulose film and demonstrated the inhibitory effect (Ming et al., 1997) on the growth of $L$. monocytogenes in concentrations of $7.75 \mu \mathrm{g} / \mathrm{cm}^{2}$. More promising results were achieved in a study conducted with pullulan film enriched with sakacin $\mathrm{A}$. The results demonstrated a significant effect, at concentrations of just $1 \mathrm{mg} / \mathrm{cm}^{2}$, of the film on the reduction of $L$. monocytogenes bacteria (Trinetta et al., 2010).

Enzymes of animal origin include lysozyme, protein isolated from hen egg and milk enzyme: lactoferrin and lactoperoxidase. The immobilization of lysosyme into the whey protein film exerted an inhibition on the growth of $L$. monocytogenes (Min $e t$ al., 2008) (Table 1). Lysosyme was added into a film from zein in combination with EDTA, enhancing the lysosyme effect against E. coli (Güçbilmez et al., 2007). More, the utilization of lysosyme in combination with nisin and EDTA on alginate film showed strong properties, inhibiting the growth of $M$. luteus, $L$. innocua, $S$. enteritidis, E. coli and S. aureus. So far, literature references have been describing the feasibility of introducing lactoferrin and lactoperoxidase to a film from whey proteins. The results demonstrated that only the film with the addition of lactoperoxidase displayed the activity against $L$. monocytogenes, $E$. coli, Salmonella enterica and Penicillium commune (Min and Krochta, 2005).

Sivarooban et al. (2008) investigated the effect of grape seeds extract introduced into soybean film (Table 1). The grape seeds extract reduced the growth of $L$. monocytogenes with 1 logarithmic unit, E. coli with 0.1 logarithmic units and $S$. typhimurium with 0.2 logarithmic units. More, the combination of grape seeds extracts with EDTA and nisin significantly enhanced the antimicrobial activity of soybean films. (Kanmani and Rhim, 2014) reported that grapefruit extract was successively introduced into carrageenan film and was effective against $M$. luteus, $L$. innocua, S. enteritidis, $E$. coli, S. aureus.

Antimicrobials preservatives used in edible films are benzoic acid, sodium benzoate, sorbic acid and potassium sorbate (Table 1). These compounds incorporated into edible films have been tested against a wide range of microorganisms. Methylcellulose and chitosan film containing $2 \%$ and $4 \%$ of sodium benzoate of potassium sorbate inhibited the growth of Penicillium notatum and Rhodotorula ruba (Chen et al., 1996).

Corn zein film with the addition of sorbic acid was shown to inhibit the growth of L. monocytogenes on sweet corn (Carlin et al., 2001). More, the sorbic acid incorporated into whey protein inhibited the growth of L. monocytogenes, E. coli, S. typhimurium on sliced bologna and summer sausage (Cagri et al., 2001; Cagri et al, 2002). The film with potassium sorbate reduced significantly the number of E. coli (Shen et al., 2010)

\section{Food applications of antimicrobial edible films}

\section{Fruits and vegetables}

Concerning nutritional aspects, fresh fruits and vegetables, stored under appropriate conditions are a veritable source of vitamins and minerals, bringing benefits to all systems in the body. A current problem with a large resonance for these products consists in the microbial load on their surface (Aponiene et al., 2015; Oliveira et al., 2015). Fruits and vegetables resistance to various microorganisms is closely correlated with a number of features: anatomical structure of the products, protective substances such as waxes, antimicrobial substances: organic acids, essential oils-feticide substances, formation of chemical compounds in place where the infection occurred (Năsui et al., 2013).

Currently, application of films to fruits and vegetables have received reasonable attention because can serve as carriers in order to maintain fresh quality, to extend product shelf life and to reduce the risk of pathogen growth (Cerqueira et al., 2009; Galus and Kadzińska, 2015; Fakhouri et al., 2015). The most important commercial properties of fruits and vegetables include colour, texture, appearance, nutritional value, flavour and microbial safety (Lin and Zhao, 2007). After harvest, the vegetal products need special conditions to reduce the biological reactions, which accelerate the natural loss of fruit tissue, water loss, change appearance and texture decreasing the commercial value of the product (Nelson, 2015; von Germeten and Hirsch, 2015).

Edible film utilization on fresh fruits and vegetables would: provide a moisture barrier on the product surface in order to decrease the moisture loss; provide a sufficient gas barrier to control gas exchange between the fresh product and its surrounding atmosphere, in an effort to slow respiration, delay 
306

Table 1. Antimicrobials incorporated in edible polymer film

\begin{tabular}{|c|c|c|c|}
\hline Antimicrobial & Polymer & Targeted microorganism & References \\
\hline \multirow[t]{2}{*}{ Oregano oil } & Soy protein & $\begin{array}{l}\text { E. coli } \mathrm{O} 157: \mathrm{H} 7 \\
\text { S. aureus } \\
\text { E. coli }\end{array}$ & Emiroğlu et al. (2010) \\
\hline & Whey protein & $\begin{array}{l}\text { E. coli } \mathrm{O} 157: \mathrm{H} 7 \\
\text { S. aureus } \\
\text { S. enteritidis } \\
\text { L. monocytogenes } \\
\text { L. plantarum }\end{array}$ & Seydim and Sarikus (2006) \\
\hline Garlic oil & Alginate & $\begin{array}{l}\text { S. aureus } \\
\text { B. subtilis } \\
\text { E. coli O157:H7 } \\
\text { E. coli } \\
\text { S. typhimurium } \\
\text { S. aureus } \\
\text { B. cereus }\end{array}$ & Liakos et al. (2014); Pranoto et al. (2005a) \\
\hline Grape seed extract & Soy protein & $\begin{array}{l}\text { Listeria monocytogenes } \\
\text { E. coli } \\
\text { S. typhimurium }\end{array}$ & Sivarooban et al. (2008) \\
\hline Grapefruit seed extract & Carrageenan & $\begin{array}{l}\text { Micrococcus luteus } \\
\text { L. innocua } \\
\text { S. enteritides } \\
\text { E. coli } \\
\text { S. aureus }\end{array}$ & Kanmani and Rhim (2014) \\
\hline Green and black teas extract & Chitosan & L. monocytogenes & Vodnar (2012) \\
\hline \multirow[t]{2}{*}{ Lysozyme } & Whey protein & L. monocytogenes & Min et al. (2008) \\
\hline & Zein & $\begin{array}{l}\text { L. plantarum } \\
\text { B. subtilis }\end{array}$ & Mecitoğlu et al. (2006) \\
\hline Lactoperoxidase & Whey protein & $\begin{array}{l}\text { L. monocytogenes } \\
\text { E. coli } \\
\text { S. enteric } \\
\text { P. commune }\end{array}$ & Min and Krochta (2005) \\
\hline Nisin & Sodium caseinate & L. monocytogenes & Cao-Hoang et al. (2010) \\
\hline Pediocin & Cellulose & L. monocytogenes & Ming et al. (1997) \\
\hline Sakacin A & Pullulan & L. monocytogenes & Trinetta et al. (2010) \\
\hline Potassium sorbate & Starch & E. coli & Shen et al. (2010) \\
\hline
\end{tabular}

deterioration and protect the fresh produce from brown discoloration and texture softening during storage; disable the exchange of volatile compounds between product and environment by providing gas barriers; protect from physical damage of produce caused by mechanical impact, pressure, vibrations and other mechanical factors; and act as carriers for other functional ingredients (Lin and Zhao, 2007).

Năsui et al. (2013) evaluated the antimicrobial effect of wash edible films containing green tea extract on red pepper, tomato, apple and nectarine. The authors found that pepper has the highest initial microbial load, followed by nectarine, apple and tomato. After fruits or vegetable washing, a slight decrease in the number of germs is happening for all mentioned products. Fruits and vegetables, which have applied label, showed a considerable decrease in the total number of germs. Edible films made from chitosan and green tea proved effectiveness in all samples, in particular on pepper, where the authors reported the absence of microorganisms on the peel after washing while on tomato were registered germs at $1 \mathrm{CFU} / \mathrm{cm}^{2}$, on apple $3 \mathrm{CFU} / \mathrm{cm}^{2}$ and on nectarine $99 \mathrm{CFU} / \mathrm{cm}^{2}$ (Fig. 1).

\section{Meat Products}

According to Juneja et al. (2006) and Friedman et al. (2009) when carvacrol was incorporated into apple films both Clostridium perfringens and $E$. coli $\mathrm{O} 157: \mathrm{H} 7$ decreased dramatically in cooked ground beef and hamburger beef patties.

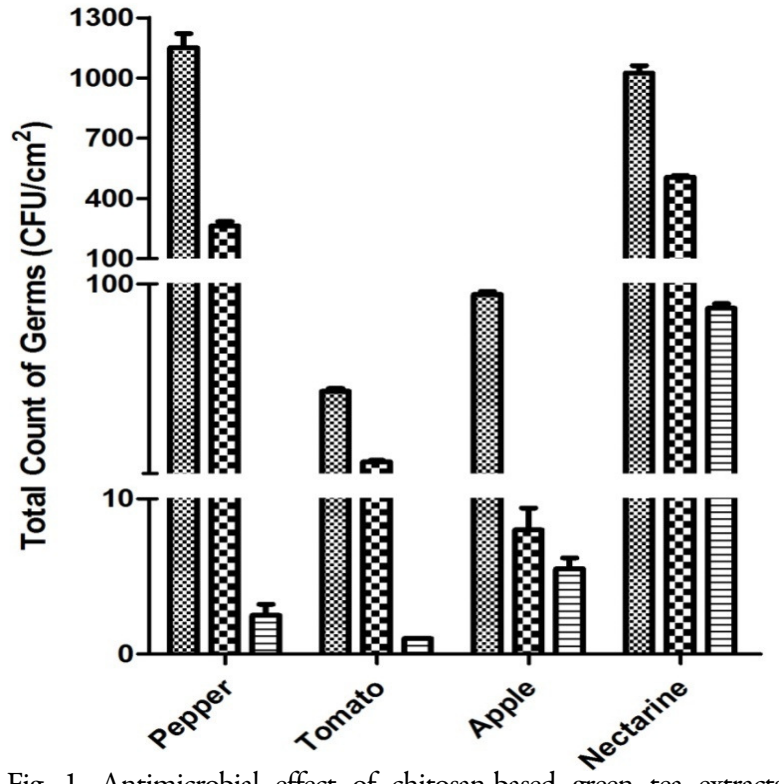

Fig. 1. Antimicrobial effect of chitosan-based green tea extracts $\$$ initial number of germs on fruits and vegetable surface; EXIfruits and vegetables conventionally washed; $\equiv$ fruits and vegetables washed with chitosan films. The antimicrobial effect quantified by the total number of germs (cfu/ $\mathrm{cm}^{2}$ ) (Nãsui et al., 2013) 


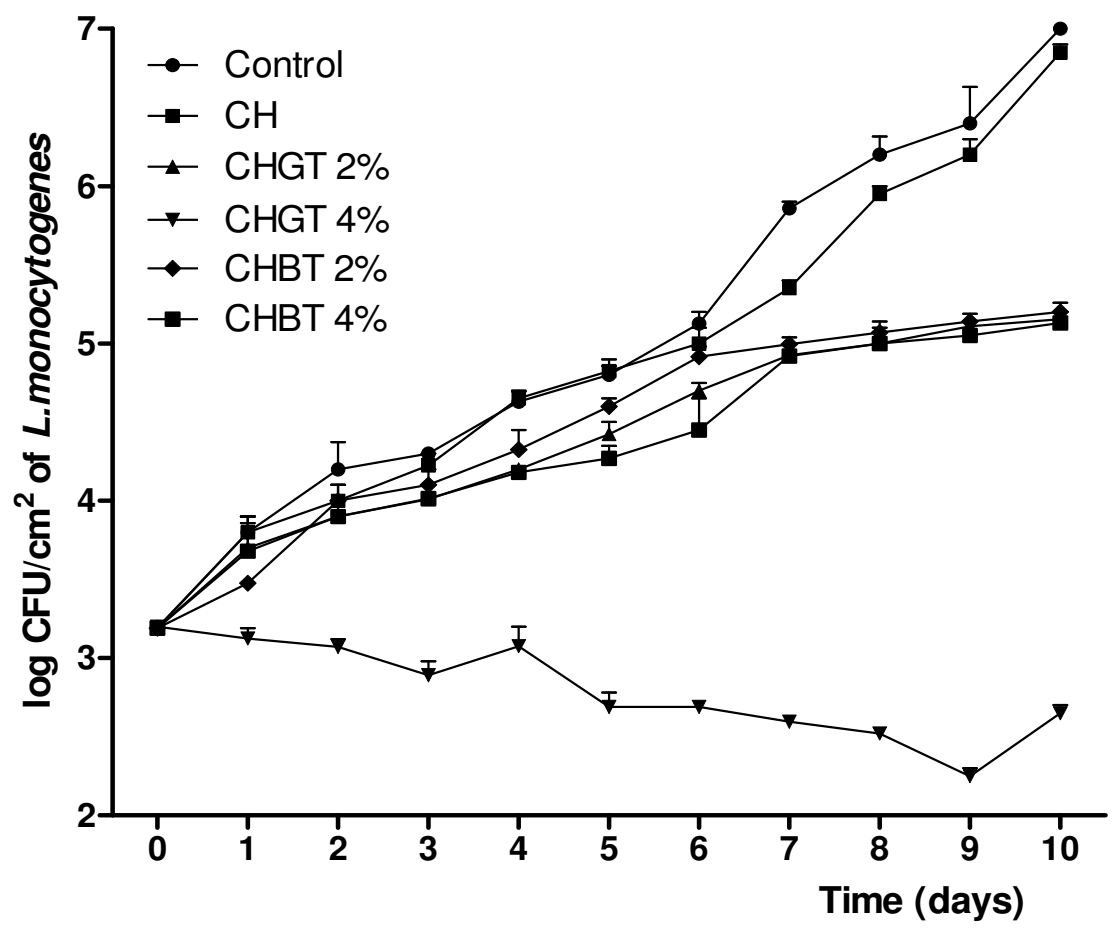

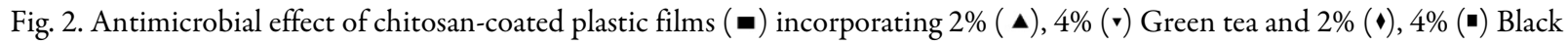
tea extracts on the growth of L. monocytogenes on ham steak at room temperature storage versus control sample (•) (Vodnar, 2012).

Emiroğlu et al. (2010) obtained a soy protein film incorporated with oregano, thyme that did not have significant effects on total viable counts. More, the authors reported when lactic acid bacteria and Staphylococcus ssp. were applied on ground beef patties significantly reductions in coliforms and Pseudomonas ssp. counts were observed. When chitosan-based antimicrobial films containing cinnamaldehyde were used on drier surfaces of meat (bologna), Enterobacteriacease and S. liquefaciens growth were delayed or completely inhibited (Ouattara et al., 2000).

The antimicrobial milk-protein-based film containing essential oils from oregano and pimento were used against $E$. coli O157:H7 and Pseudomonas ssp. in preserving whole beef muscle (Oussalah et al., 2004). Incorporating oregano extract into film showed more effective antimicrobial ability, achieving reductions of around $1 \log$ unit for each bacterial species at the end of storage compared with uncoated samples.

Previous study reported by Vodnar (2012) combined the properties of a chitosan film with green and black tea extracts. Incorporation of tea extracts into the chitosan films considerably enhanced the effectiveness against $L$. monocytogenes ATCC 19115 on ham steak.

Green tea (4\%) incorporated into chitosan-coated plastic film had a better antilisterial effect than green tea $2 \%$ or black tea $2 \%$ and $4 \%$. Data from study provided new establishment options for developing antimicrobial packaging films using tea extracts in order to improve the microbiological safety and quality of ham steak during room and refrigerated storage (Vodnar, 2012).
The initial concentration of $L$. monocytogenes ATCC 19115 on inoculated ham steak samples was $3.2 \log \mathrm{CFU} / \mathrm{cm}^{2}$ (Fig. 2). L. monocytogenes ATCC 19115 in chitosan-coated plastic films grew to $6.8 \mathrm{log} \mathrm{CFU} / \mathrm{cm}^{2}$ after 10 days of storage at room temperature. Incorporating natural extracts into chitosan showed that the growth of L. monocytogenes ATCC 19115 was inhibited. The efficacy of antimicrobial effect of tea extracts incorporated into chitosan-coated plastic film was dose dependent. The $2 \%$ green tea and $2 \%, 4 \%$ black tea extracts had inhibitory effect on L. monocytogenes ATCC 19115 but the most efficient antimicrobial effect has been registered by $4 \%$ green tea.

Inoculated ham steak samples with an initial population of $3.2 \log \mathrm{CFU} / \mathrm{cm}^{2}$, were stored at $4^{\circ} \mathrm{C}$ for 8 weeks. Counts of $L$. monocytogenes ATCC 19115 on ham steak samples treated with chitosan-coated film incorporating tea extracts are shown in Fig.3. In the first 4 weeks, L. monocytogenes ATCC 19115 in control and chitosan-coated plastic film grew very slowly from 3.2 to $4.3 \log \mathrm{CFU} / \mathrm{cm}^{2}$. The tea extracts addition into chitosancoated films were effective against $L$ monocytogenes ATCC 19115 and reduced its counts from 3.2 to $1-1.5 \mathrm{log} \mathrm{CFU} / \mathrm{cm}^{2}$ during 8 weeks of storage. In general, the gram negative bacteria are more resistant to polyphenols than Gram positive bacteria, perhaps due to the different cell wall compositions (Mocan et al., 2014; Negi et al., 2003).

Gómes-Estaca et al. (2010) reported that gelatinchitosan film incorporating clove essential oils reduced drastically the population of gram-negative bacteria on 


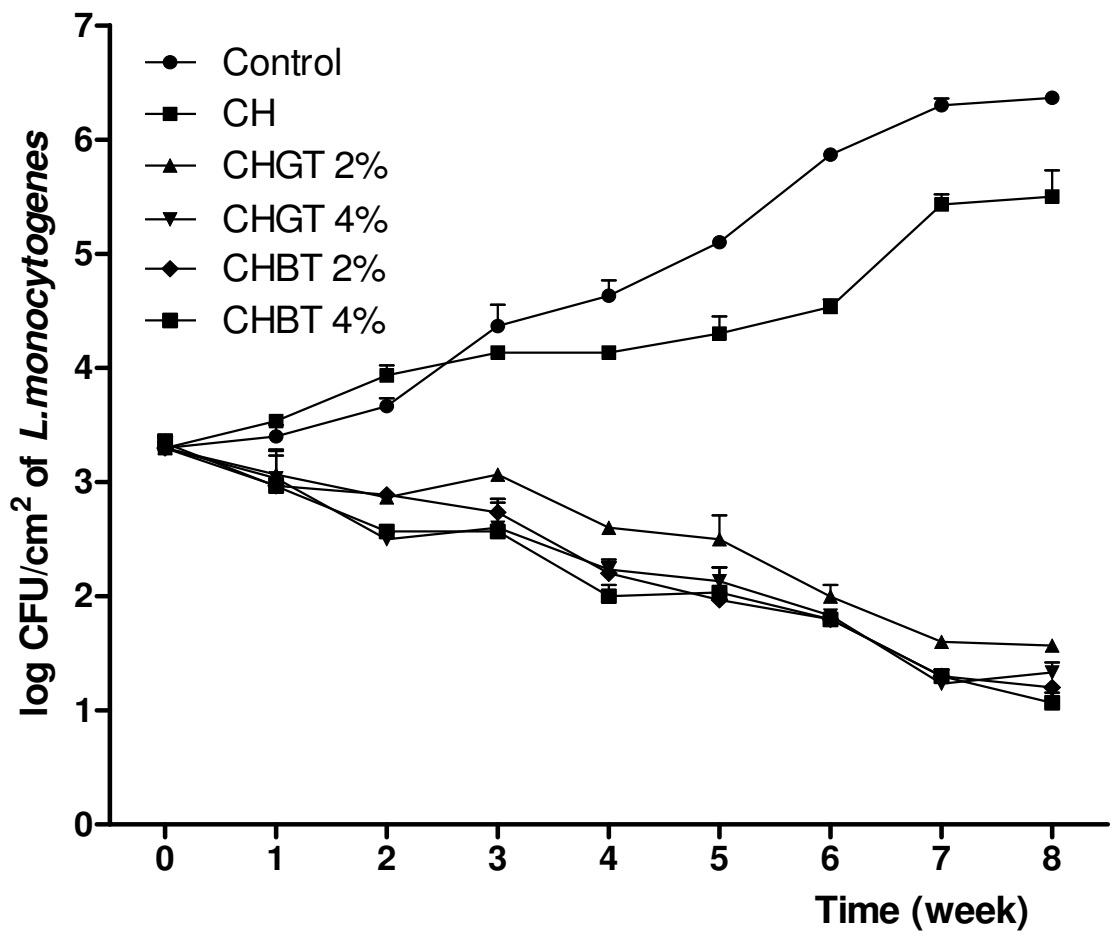

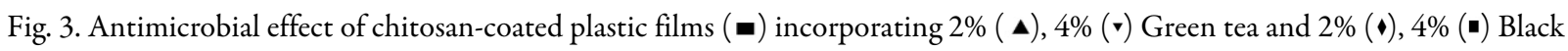
tea extracts on the growth of L. monocytogenes on ham steak store at $4^{\circ} \mathrm{C}$ versus control sample $(\bullet)$ (Vodnar, 2012)

codfish during chilled storage. More, Gómes-Estaca et al. (2007) reported that the stability of cold-smoked sardine muscle was improved by coating the muscle with functional gelatine film.

\section{Conclusions}

Antimicrobial packaging is very promising system for the future improvement in food quality and preservation during processing and storage. Natural antimicrobials as one of the food preservative ingredient are expected to substitute synthetic additives for fulfilling the demand of the consumers on safer food additives. The functional properties of natural polymers can be improved when edible films are combined with natural antimicrobial compounds. Antimicrobial packaging films made from biodegradable and food grade materials, are promising food packaging materials because their proprieties ensure a sustainable development for the modern community.

\section{Acknowledgements}

This work was supported by the Partnership in Priority Areas Programme-PNII, developed with the support of MEN-UEFISCDI (Project No.154 [PN-II-PT-PCCA2013-4-0743]).

\section{References}

Acevedo-Fani A, Salvia-Trujillo L, Rojas-Graü MA, MartínBelloso O (2015). Edible films from essential-oil-loaded nanoemulsions: Physicochemical characterization and antimicrobial properties. Food Hydrocolloids 47:168-177.

Agarwal S (2012). Biodegradable polyesters. In: Matyjaszewski K, Möller M (Eds). Polymer Science: A Comprehensive Reference, Amsterdam: Elsevier BV pp 333-361.

Akhavan M, Jahangiri S, Shafaghat A (2015). Studies on the antioxidant and antimicrobial activity and flavonoid derivatives from the fruit of Trigonosciadium brachytaenium (Boiss.) Alava. Industrial Crops and Products 63:114-118.

Akter N, Khan RA, Salmieri S, Sharmin N, Dussault D, Lacroix $M$ (2012). Fabrication and mechanical characterization of biodegradable and synthetic polymeric films: Effect of gamma radiation. Radiation Physics and Chemistry 81:995-998.

Angiolillo L, Conte A, Del Nobile MA (2014). Food Additives: Natural Preservatives. In: Motarjemi Y (Ed). Encyclopedia of Food Safety. Academic Press, Waltham pp. 474-476.

Ankri S, Mirelman D (1999). Antimicrobial properties of allicin from garlic. Microbes and Infections 1:125-129.

Aponiene K, Paskeviciute E, Reklaitis I, Luksiene Z (2015). Reduction of microbial contamination of fruits and vegetables by hypericin-based photosensitization: Comparison with other emerging antimicrobial treatments. Journal of Food Engineering 144:29-35. 
Armentano I, Bitinis N, Fortunati E, Mattioli S, Rescignano N, Verdejo R, Lopez-Manchado MA, Kenny JM (2013). Multifunctional nanostructured PLA materials for packaging and tissue engineering. Progress in Polymer Science 38:17201747.

Atarés L, Bonilla J, Chiralt A (2010). Characterization of sodium caseinate-based edible films incorporated with cinnamon or ginger essential oils. Journal of Food Engineering 100:678687.

Aumeeruddy-Elalfi Z, Gurib-Fakim A, Mahomoodally F (2015). Antimicrobial, antibiotic potentiating activity and phytochemical profile of essential oils from exotic and endemic medicinal plants of Mauritius. Industrial Crops and Products 71:197-204.

Banerjee R, Chen H (1995). Functional properties of edible films using whey protein concentrate. Journal of Dairy Science 78:1673-1683.

Basgedik B, Ugur A, Sarac N (2015). Antimicrobial, antioxidant and antimutagenic properties of Iris albicans. Industrial Crops and Products 69:480-484.

Bayarri M, Oulahal N, Degraeve P, Gharsallaoui A (2014). Properties of lysozyme/low methoxyl (LM) pectin complexes for antimicrobial edible food packaging. Journal of Food Engineering 131:18-25.

Benito-Peña E, González-Vallejo V, Rico-Yuste A, BarbosaPereira L, Cruz JM, Bilbao A, Alvarez-Lorenzo C, MorenoBondi MC (2016). Molecularly imprinted hydrogels as functional active packaging materials. Food Chemistry 190:487-494.

Bonilla J, Atarés L, Vargas M, Chiralt A (2012). Edible films and coatings to prevent the detrimental effect of oxygen on food quality: Possibilities and limitations. Journal of Food Engineering 110:208-213.

Cagri A, Ustunol Z, Ryser ET (2001). Antimicrobial, Mechanical, and moisture barrier properties of low $\mathrm{pH}$ whey protein-based edible films containing p-aminobenzoic or sorbic acids. Journal of Food Science 66:865-870.

Cagri A, Ustunol Z, Ryser ET (2002). Inhibition of three pathogens on Bologna and Summer Sausage using antimicrobial edible films. Journal of Food Science 67:23172324.

Calo JR, Crandall PG, O’Bryan CA, Ricke SC (2015). Essential oils as antimicrobials in food systems - A review. Food Control 54:111-119.

Cao-Hoang L, Grégoire L, Chaine A, Waché Y (2010). Importance and efficiency of in-depth antimicrobial activity for the control of listeria development with nisin-incorporated sodium caseinate films. Food Control 21:1227-1233.

Carlin F, Gontard N, Reich M, Nguyen-The C (2001). Utilization of zein coating and sorbic acid to reduce listeria monocytogenes growth on cooked sweet corn. Journal of Food Science 66:1385-1389.

Carson CF, Mee BJ, Riley TV (2002). Mechanism of action of Melaleuca alternifolia (tea tree) oil on Staphylococcus aureus determined by time-kill, lysis, leakage, and salt tolerance assays and electron microscopy. Antimicrobial Agents and Chemotherapy 46:1914-1920.

Casariego A, Souza BWS, Vicente AA, Teixeira JA, Cruz L, Díaz $R$ (2008). Chitosan coating surface properties as affected by plasticizer, surfactant and polymer concentrations in relation to the surface properties of tomato and carrot. Food Hydrocolloids 22:1452-1459.

Cerqueira MA, Lima ÁM, Teixeira JA, Moreira RA, Vicente AA(2009). Suitability of novel galactomannans as edible coatings for tropical fruits. Journal of Food Engineering 94:372-378.

Chen M-C, Yeh GH-C, Chiang B-H (1996). Antimicrobial and physicochemical properties of methylcellulose and chitosan films containing a preservative. Journal of Food Processing and Preservation 20:379-390.

Cho SY, Rhee C (2004). Mechanical properties and water vapor permeability of edible films made from fractionated soy proteins with ultrafiltration. LWT-Food Science and Technology 37:833-839.

Coma V, Sebti I, Pardon P, Deschamps A, Pichavant FH (2001). Antimicrobial edible packaging based on cellulosic ethers, fatty acids, and nisin incorporation to inhibit Listeria innocua and Staphylococcus aureus. Journal of Food Protection 64:470-5.

Cottigli F, Loy G, Garau D, Floris C, Caus M, Pompei R, Bonsignore L (2001). Antimicrobial evaluation of coumarins and flavonoids from the stems of Daphne gnidium L. Phytomedicine 8:302-305.

Cuero RG, Osuji G, Washington A (1991). Ncarboxymethylchitosan inhibition of aflatoxin production: Role of zinc. Biotechnology Letters 13:441-444.

De Azeredo HMC (2013). Antimicrobial nanostructures in food packaging. Trends in Food Science and Technology 30:56-69.

De'nobili MD, Rojas AM, Abrami M, Lapasin R, Grassi M (2015). Structure characterization by means of rheological and NMR experiments as a first necessary approach to study the l(+)-ascorbic acid diffusion from pectin and pectin/alginate films to agar hydrogels that mimic food materials. Journal of Food Engineering 165:82-92.

Del Nobile MA, Conte A, Buonocore GG, Incoronato AL, Massaro A, Panza O (2009). Active packaging by extrusion processing of recyclable and biodegradable polymers. Journal of Food Engineering 93:1-6.

Djidi D, Mignard N, Taha M (2015). Thermosensitive polylacticacid-based networks. Industrial Crops and Products 72:220230.

Dutta PK, Tripathi S, Mehrotra GK, Dutta J (2009). Perspectives for chitosan based antimicrobial films in food applications. Food Chemistry 114:1173-1182.

Emiroğlu ZK, Yemiş GP, Coşkun BK, Candoğan K (2010). Antimicrobial activity of soy edible films incorporated with thyme and oregano essential oils on fresh ground beef patties. Meat Science 86:283-288.

Fakhouri FM, Martelli SM, Caon T, Velasco JI, Mei LHI (2015). Edible films and coatings based on starch/gelatin: Film 
310

properties and effect of coatings on quality of refrigerated Red Crimson grapes. Postharvest Biology and Technology 109:5764.

Friedman M, Buick R, Elliott CT (2004). Antibacterial activities of naturally occurring compounds against antibiotic-resistant Bacillus cereus vegetative cells and spores, Escherichia coli, and Staphylococcus aureus. Journal of Food Protection 67:1774-8.

Friedman M, Henika PR, Mandrell RE (2002). Bactericidal activities of plant essential oils and some of their isolated constituents against Campylobacter jejuni, Escherichia coli, Listeria monocytogenes, and Salmonella enterica. Journal of Food Protection 65:1545-60.

Friedman M, Zhu L, Feinstein Y, Ravishankar S (2009). Carvacrol facilitates heat-induced inactivation of Escherichia coli O157:H7 and Inhibits formation of heterocyclic amines in grilled ground beef patties. Journal of Agricultural and Food Chemistry 57:1848-1853.

Galus S and Kadzińska J (2015). Food applications of emulsionbased edible films and coatings. Trends in Food Science and Technology 45:273-283.

Ge L, Li X, Zhang R, Yang T, Ye X, Li D, Mu C (2015). Development and characterization of dialdehyde xanthan gum crosslinked gelatin based edible films incorporated with amino-functionalized montmorillonite. Food Hydrocolloids 51:129-135.

Genskowsky E, Puente LA, Pérez-Álvarez JA, Fernandez-Lopez J, Muñoz LA, Viuda-Martos M (2015). Assessment of antibacterial and antioxidant properties of chitosan edible films incorporated with maqui berry (Aristotelia chilensis). LWT-Food Science and Technology 64:1057-1062.

Gomez-Estaca J, Lopez De Lacey A, Lopez-Caballero ME, Gomez-Guillen MC, Montero P (2010). Biodegradable gelatin-chitosan films incorporated with essential oils as antimicrobial agents for fish preservation. Food Microbiology 27:889-96.

Gómez-Estaca J, Montero P, Giménez B, Gómez-Guillén MC (2007). Effect of functional edible films and high pressure processing on microbial and oxidative spoilage in cold-smoked sardine (Sardina pilchardus). Food Chemistry 105:511-520.

Güçbilmez ÇM, Yemenicioğlu A, Arslanoğlu A (2007). Antimicrobial and antioxidant activity of edible zein films incorporated with lysozyme, albumin proteins and disodium EDTA. Food Research International 40:80-91.

Hambleton A, Voilley A, Debeaufort F (2011). Transport parameters for aroma compounds through $\mathrm{i}$-carrageenan and sodium alginate-based edible films. Food Hydrocolloids 25:1128-1133.

Han JH (2014). Edible Films and Coatings: A Review. In: Han $\mathrm{JH}$ (Ed). Innovations in Food Packaging (Second Edition), Academic Press, San Diego pp. 213-255.

Hoffman KL, Han IY, Dawson PL (2001). Antimicrobial effects of corn zein films impregnated with nisin, lauric acid, and EDTA. Journal of Food Protection 64:885-9.
Ingrao C, Tricase C, Cholewa-Wójcik A, Kawecka A, Rana R, Siracusa V (2015). Polylactic acid trays for fresh-food packaging: A Carbon Footprint assessment. Science of the Total Environment 537:385-398.

Jašo V, Glenn G, Klamczynski A, Petrović ZS (2015). Biodegradability study of polylactic acid/ thermoplastic polyurethane blends. Polymer Testing 47:1-3.

Jayakumar R, Nwe N, Tokura $S$ and Tamura H (2007). Sulfated chitin and chitosan as novel biomaterials. International Journal of Biological Macromolecules 40:175-181.

Juneja VK, Thippareddi H, Friedman M (2006). Control of Clostridium perfringens in cooked ground beef by carvacrol, cinnamaldehyde, thymol, or oregano oil during chilling. Journal of Food Protection 69:1546-51.

Kanmani P, Rhim J-W (2014). Development and characterization of carrageenan/grapefruit seed extract composite films for active packaging. International Journal of Biological Macromolecules 68:258-266.

Keawchaoon L, Yoksan R (2011). Preparation, characterization and in vitro release study of carvacrol-loaded chitosan nanoparticles. Colloids and Surfaces B: Biointerfaces 84:163171.

Khan MKI, Schutyser MaI, Schroën K, Boom R (2012). The potential of electrospraying for hydrophobic film coating on foods. Journal of Food Engineering 108:410-416.

Ko S, Janes ME, Hettiarachchy NS, Johnson MG (2001). Physical and chemical properties of edible films containing nisin and their action against Listeria monocytogenes. Journal of Food Science 66:1006-1011.

Kon KV, Rai MK (2013). Combining essential oils with antibiotics and other antimicrobial agents to overcome multidrug-resistant bacteria. In: Kon MKRV (Ed). Fighting multidrug resistance with herbal extracts, essential oils and their components. Academic Press, San Diego pp 149-164.

Laurent MA, Boulenguer P (2003). Stabilization mechanism of acid dairy drinks (ADD) induced by pectin. Food Hydrocolloids 17:445-454.

Liakos I, Rizzello L, Scurr DJ, Pompa PP, Bayer IS, Athanassiou A (2014). All-natural composite wound dressing films of essential oils encapsulated in sodium alginate with antimicrobial properties. International Journal of Pharmaceutics 463:137-145.

Lin D, Zhao Y (2007). Innovations in the development and application of edible coatings for fresh and minimally processed fruits and vegetables. Comprehensive Reviews in Food Science and Food Safety 6:60-75.

Lv F, Liang H, Yuan Q, Li C (2011). In vitro antimicrobial effects and mechanism of action of selected plant essential oil combinations against four food-related microorganisms. Food Research International 44:3057-3064.

Madureira AR, Pereira A, Castro PM, Pintado M (2015). Production of antimicrobial chitosan nanoparticles against food pathogens. Journal of Food Engineering 167(Part B):210-216. 
Mahalik NP, Nambiar AN (2010). Trends in food packaging and manufacturing systems and technology. Trends in Food Science and Technology 21:117-128.

Mahieu A, Terrié C, Youssef B (2015). Thermoplastic starch films and thermoplastic starch/polycaprolactone blends with oxygen-scavenging properties: Influence of water content. Industrial Crops and Products 72:192-199.

Marcos B, Sárraga C, Castellari M, Kappen F, Schennink G, Arnau J (2014). Development of biodegradable films with antioxidant properties based on polyesters containing $\alpha$ tocopherol and olive leaf extract for food packaging applications. Food Packaging and Shelf Life 1(2):140-150.

Martucci JF, Gende LB, Neira LM, Ruseckaite RA (2015). Oregano and lavender essential oils as antioxidant and antimicrobial additives of biogenic gelatin films. Industrial Crops and Products 71:205-213.

McHugh TH, Aujard JF and Krochta JM (1994). Plasticized whey protein edible films: Water vapor permeability properties. Journal of Food Science 59:416-419.

Mecitoğlu Ç, Yemenicioğlu A, Arslanoğlu A, Elmacı ZS, Korel F, Çetin AE (2006). Incorporation of partially purified hen egg white lysozyme into zein films for antimicrobial food packaging. Food Research International 39:12-21.

Mihaly Cozmuta A, Turila A, Apjok R, Ciocian A, Mihaly Cozmuta L, Peter A, Nicula C, Galić N, Benković T (2015). Preparation and characterization of improved gelatin films incorporating hemp and sage oils. Food Hydrocolloids 49:144-155.

Min S, Krochta JM (2005). Inhibition of Penicillium commune by edible whey protein films incorporating lactoferrin, lactoferrin hydrolysate, and lactoperoxidase systems. Journal of Food Science 70:M87-M94.

Min S, Rumsey TR, Krochta JM (2008). Diffusion of the antimicrobial lysozyme from a whey protein coating on smoked salmon. Journal of Food Engineering 84:39-47.

Ming X, Weber GH, Ayres JW, Sandine WE (1997). Bacteriocins applied to food packaging materials to inhibit Listeria monocytogenes on meats. Journal of Food Science 62:413-415.

Mocan A, Vlase L, Vodnar DC, Bischin C, Hanganu D, Gheldiu AM, Oprean R, Silaghi-Dumitrescu R, Crisan G (2014). Polyphenolic content, antioxidant and antimicrobial activities of Lycium barbarum L. and Lycium chinense Mill. leaves. Molecules 19:10056-73.

Moller H, Grelier S, Pardon P, Coma V (2004). Antimicrobial and physicochemical properties of chitosan-HPMC-based films. Journal of Agricultural and Food Chemistry 52:658591.

Năsui L, Vodnar D, Socaciu C (2013). Bioactive labels for fresh fruits and vegetables. Bulletin UASVM Food Science and Technology 70(2):75-83.

Negi PS, Jayaprakasha GK, Jena BS (2003). Antioxidant and antimutagenic activities of pomegranate peel extracts. Food Chemistry 80:393-397.
Nelson SO (2015). Quality sensing in fruits and vegetables. In: Nelson SO (Ed). Dielectric properties of agricultural materials and their applications. Academic Press, San Diego pp 123130.

Oliveira M, Abadias M, Usall J, Torres R, Teixidó N, Viñas I (2015). Application of modified atmosphere packaging as a safety approach to fresh-cut fruits and vegetables - A review. Trends in Food Science and Technology 46:13-26.

Ollé Resa CP, Gerschenson LN, Jagus RJ (2014). Natamycin and nisin supported on starch edible films for controlling mixed culture growth on model systems and Port Salut cheese. Food Control 44:146-151.

Ouattara B, Simard RE, Piette G, Bégin A, Holley RA (2000). Inhibition of surface spoilage bacteria in processed meats by application of antimicrobial films prepared with chitosan. International Journal of Food Microbiology 62:139-148.

Oussalah M, Caillet S, Salmiéri S, Saucier L, Lacroix M (2004). Antimicrobial and antioxidant effects of milk protein-based film containing essential oils for the preservation of whole beef muscle. Journal of Agricultural and Food Chemistry 52:55985605.

Ozdemir M, Floros JD (2008). Optimization of edible whey protein films containing preservatives for water vapor permeability, water solubility and sensory characteristics. Journal of Food Engineering 86:215-224.

Pattanayaiying R, H-Kittikun A, Cutter CN (2015). Optimization of formulations for pullulan films containing lauric arginate and nisin Z. LWT-Food Science and Technology 63:1110-1120.

Pesavento G, Calonico C, Bilia AR, Barnabei M, Calesini F, Addona R, Mencarelli L, Carmagnini L, Di Martino MC, Lo Nostro A (2015). Antibacterial activity of Oregano, Rosmarinus and Thymus essential oils against Staphylococcus aureus and Listeria monocytogenes in beef meatballs. Food Control 54:188-199.

Pop OL, Vodnar DC, Suharoschi R, Mudura E, Socaciu C (2015). L. plantarum ATCC 8014 entrapment with prebiotics and lucerne green juice and their behavior in simulated gastrointestinal conditions. Journal of Food Process Engineering. doi:10.1111/jfpe.12234.

Pranoto Y, Salokhe VM, Rakshit SK (2005a). Physical and antibacterial properties of alginate-based edible film incorporated with garlic oil. Food Research International 38:267-272.

Pranoto Y, Salokhe VM, Rakshit SK (2005b). Physical and antibacterial properties of alginate-based edible film incorporated with garlic oil. Food Research International $38: 267-272$.

Quintavalla S, Vicini L (2002). Antimicrobial food packaging in meat industry. Meat Science 62:373-380.

Rabea EI, Badawy ME, Stevens CV, Smagghe G, Steurbaut W (2003). Chitosan as antimicrobial agent: applications and mode of action. Biomacromolecules 4:1457-65. 
312

Ramani M, Ponnusamy S, Muthamizhchelvan C, Marsili E (2014). Amino acid-mediated synthesis of zinc oxide nanostructures and evaluation of their facet-dependent antimicrobial activity. Colloids and Surfaces B: Biointerfaces 117:233-239.

Rhim J-W (2013). Preparation and characterization of vacuum sputter silver coated PLA film. LWT-Food Science and Technology 54:477-484.

Ríos JL, Recio MC (2005). Medicinal plants, antimicrobial activity. Journal of Ethnopharmacology 100:80-84.

Salleh E, Muhamad I, Khairuddin N (2007). Preparation, characterization and antimicrobial analysis of antimicrobial starch-based film incorporated with chitosan and lauric acid. Asian Chitin Journal 3: 55-68.

Salgado PR, Ortiz CM, Musso YS, Di Giorgio L, Mauri AN (2015). Edible films and coatings containing bioactives. Current Opinion Food Science. doi: http://dx.doi.org/doi:10.1016/j.cofs.2015.09.004

Seydim AC, Sarikus G (2006). Antimicrobial activity of whey protein based edible films incorporated with oregano, rosemary and garlic essential oils. Food Research International 39:639-644.

Shahidi F, Arachchi JKV, Jeon Y-J (1999). Food applications of chitin and chitosans. Trends in Food Science and Technology 10:37-51.

Shen XL, Wu JM, Chen Y, Zhao G (2010). Antimicrobial and physical properties of sweet potato starch films incorporated with potassium sorbate or chitosan. Food Hydrocolloids 24:285-290.

Sivarooban T, Hettiarachchy NS, Johnson MG (2008). Physical and antimicrobial properties of grape seed extract, nisin, and EDTA incorporated soy protein edible films. Food Research International 41:781-785.

Song J, Jang J (2014). Antimicrobial polymer nanostructures: Synthetic route, mechanism of action and perspective. Advances in Colloid and Interface Science 203:37-50.

Srey S, Jahid IK, Ha S-D (2013). Biofilm formation in food industries: A food safety concern. Food Control 31:572-585.

Sung S-Y, Sin LT, Tee T-T, Bee S-T, Rahmat AR, Rahman WaWA, Tan A-C, Vikhraman M (2013). Antimicrobial agents for food packaging applications. Trends in Food Science and Technology 33:110-123.

Suyatma NE, Tighzert L, Copinet A, Coma V (2005). Effects of hydrophilic plasticizers on mechanical, thermal, and surface properties of chitosan films. Journal of Agricultural and Food Chemistry 53:3950-3957.

Terzopoulou ZN, Papageorgiou GZ, Papadopoulou E, Athanassiadou E, Alexopoulou E, Bikiaris DN (2015). Green composites prepared from aliphatic polyesters and bast fibers. Industrial Crops and Products 68:60-79.
Tharanathan RN (2003). Biodegradable films and composite coatings: past, present and future. Trends in Food Science and Technology 14:71-78.

Tong Z, Ni L, Ling J (2014). Antibacterial peptide nisin: A potential role in the inhibition of oral pathogenic bacteria. Peptides 60:32-40.

Trinetta V, Floros JD, Cutter CN (2010). Sakacin a-containing pullulan film: an active packaging system to control epidemic clones of listeria monocytogenes in ready-to-eat foods. Journal of Food Safety 30:366-381.

Tripathi S, Mehrotra GK, Dutta PK (2010). Preparation and physicochemical evaluation of chitosan/poly(vinyl alcohol)/pectin ternary film for food-packaging applications. Carbohydrate Polymers 79:711-716.

Videcoq P, Garnier C, Robert P, Bonnin E (2011). Influence of calcium on pectin methylesterase behaviour in the presence of medium methylated pectins. Carbohydrate Polymers 86:1657-1664.

Vodnar DC, Paucean A, Dulf FV, Socaciu C (2010). HPLC characterization of lactic acid formation and FTIR fingerprint of probiotic bacteria during fermentation processes. Notulae Botanicae Horti Agrobotanici 38(2):109-113.

Vodnar DC (2012). Inhibition of Listeria monocytogenes ATCC 19115 on ham steak by tea bioactive compounds incorporated into chitosan-coated plastic films. Journal of Food Safety 6:7474.

Von Germeten J-P, Hirsch S (2015). Pre-sliced or do it yourself?Determinants of schoolchildren's acceptance of convenience fruits and vegetables. Food Quality Preference 44:1-11.

Wang G, Mishra B, Lau K, Lushnikova T, Golla R, Wang X (2015). Antimicrobial Peptides in 2014. Pharmaceuticals $8: 123$.

Wang Y, Zhang Q, Zhang C-L, Li P (2012). Characterisation and cooperative antimicrobial properties of chitosan/nano- $\mathrm{ZnO}$ composite nanofibrous membranes. Food Chemistry 132:419-427.

Zabka M, Pavela R, Prokinova E (2014). Antifungal activity and chemical composition of twenty essential oils against significant indoor and outdoor toxigenic and aeroallergenic fungi. Chemosphere 112:443-448.

Zheng L-Y, Zhu J-F (2003). Study on antimicrobial activity of chitosan with different molecular weights. Carbohydrate Polymers 54:527-530.

Zivanovic S, Chi S, Draughon AF (2005). Antimicrobial activity of chitosan films enriched with essential oils. Journal of Food Science 70:M45-M51. 